\title{
Hermit Hero in the Context of "New Prose" Social Realism by Maxim Gorky
}

\section{El héroe solitario en el contexto del realismo social de la "prosa nueva" de Máximo Gorki}

\author{
Gurtueva Tamara \\ Yeditepe University, Istanbul, Turkey \\ ORCID ID: https://orcid.org/0000-0002-6402-885X \\ Gunes Bahar \\ Ankara University of Social Sciences, Ankara, Turkey \\ ORCID ID: https://orcid.org/0000-0002-0975-1172 \\ Olga Fisenko $D *$ \\ Peoples' Friendship University of Russia (RUDN University), Moscow, Russian \\ Federation \\ ORCID ID: https://orcid.org/0000-0002-3824-5535
}

Received 07-07-20 Revised 09-25-20 Accepted 01-13-21 On line 01-25-21

*Correspondencia

Email: OlgaFisenko@gmail.com
Citar como:

Gurtueva, T., Gunes, B., Fisenko, O. (2021). Hermit Hero in the Context of "New Prose" Social Realism by Maxim Gorky. Propósitos y Representaciones, 9(SPE2), e951. Doi http://dx.doi.org/10.20511/pyr2021.v9nSPE2.951 


\section{Summary}

It is proved that the works by Maxim Gorky are inseparable from the socio-historical reality of the early XX-th century. Maxim Gorky is a writer, whose work has evolved throughout his career. One of the values in the works by Maxim Gorky is the image of the hero - the hermit, presented in the "Tales of 1922-1924". The semantic space of the hermit hero image exists at the intersection of the semantic fields "social status", "nature", "hero image", "love" and "service to people".

Keywords: Maxim Gorky, hermit, “Tales of 1922 - 1924”.

\section{Resumen}

El objetivo del presente trabajo es demostrar que existe un vínculo indisoluble entre la obra de Máximo Gorki y la realidad social e histórica de los principios del singlo XX. La obra de Máximo Gorki fue evolucionando a lo largo de su trayectoria literaria. Uno de los aspectos más relevantes de la obra de Máximo Gorki es la figura del héroe solitario que aparece en los relatos de los años 1922 -1924. Podemos encontrar el espacio semántico del héroe solitario en el punto de convergencia de los campos semánticos "posición social", "naturaleza", "figura del héroe", "amor" y "servicio a los demás".

Palabras clave: Máximo Gorki, héroe solitario, relatos de los años 1922 - 1924.

\section{Introducción}

Maxim Gorky is one of the most famous representatives of social realism during the first third of the 20th century. A unique creative manner, a unique artistic world, an unusually picturesque system of characters makes his work interesting for the modern reader. Throughout his entire creative career, the writer himself searched for new forms of poetic expression means. During the post-revolutionary period, changes are observed in the works by Maxim Gorky. The writer's turn on a new path, "the changes in his literary sympathies indicate profound changes that have taken place in Russian literature" (Shklovsky 1990, p. 211). The artistic style of the writer Gorky during the 1920-ies was most accurately described by K.A. Fedin: "A true, fearless artist, he listened to advice, tested himself with a variety of tastes. Gorky went through the period of stormy and persistent revision of his artistic techniques during the early 1920-ies, after which wonderful books of stories and memoirs appeared that adorned everything that Gorky created" (Fedin 1961, p. 97).

\section{Problem development level}

Gorky's creative legacy has repeatedly become the object of research interest of scholars, politicians and public figures. However, despite the presence of a large amount of critical literature related to the study of Gorky's work, the series "Tales of 1922 - 1924" are studied poorly, despite the fact that they were published 7 times. The stories were read by a large audience, but they did not get a feedback from the critics both in Soviet Russia and among the Russian emigration. The analysis of the critical literature showed that critics bypassed the series "Tales of 1922-1924" until the middle of the 20-th century (the time of Stalin's death). During the Khrushchev's thaw, a new period began in the study of Gorky's stories. But both during this and the subsequent periods, the study of stories was of an episodic one.

The lack of a comprehensive analysis of Gorky's stories was associated with an unusual and complex artistic design. Creating "new prose", the writer has done a tremendous job of past experience rethinking. K.G. Locks noted M. Gorky's addiction to the choice of exceptional phenomena of a national character (Locks 1926, p. 22). 
The works by V.I. Baranov, B.A. Bialik, A.A. Volkov, M.N. Klimov, A.I. Ovcharenko, I.N. Sukhikh, K.A. Fedin and a number of other Soviet, Russian critics, as well as the Russian diaspora are devoted to the study of "Tales of 1922 - 1924".

K.A. Fedin wrote: "Gorky clearly expressed his line of restless search for a new form in a letter to me. Having sent the manuscript of the story "About cockroaches", he asked me to write about the impression: "It would be very interesting and useful for me to know if something is flickering in him that is not "from Gorky"? - this is a serious question for me <...>". Gorky could have been calm, because everything written by him over the last decade and a half of his life as a writer, very much was "not from Gorky", more precisely, from the new Gorky" (Fedin 1961, p. 98).

Maxim Gorky's contemporaries and descendants drew attention to the uniqueness of Gorky's "new" prose. At the same time, despite the changes in mood, Maxim Gorky was true to himself, and to his talent as a creator.

\section{Discussion Problems}

\section{Gorky}

Social discourse of the third decade of the XX-th century and "new prose" by Maxim

Social discourse of the post-revolutionary Soviet Union is an ambiguous phenomenon that requires special research attention. As a socio-cultural code, social discourse makes it possible to understand the linguistic culture of the country and the writer's role in it. The formation of Gorky's socio-psychological social discourse at the beginning of the 20 -th century was influenced by his spiritual crisis associated with the post-revolutionary period.

The revolutionary events of the early XX-th century radically changed the socio-political picture, which was fully reflected in the literature. Social discourse models social processes of the past, present and future fundamental changes in the socio-political way of life. Literary social discourse synthesizes social criticism, ideological content and aesthetic function. At the same time, aesthetics and politics are not only the reflection of the ideology and politics of the young state, but also largely determine its ideology and politics. A common feature of social discourse is ideologization, adherence to a generally accepted doctrine. During the post-revolutionary period, Russian literature of the end is characterized by the predominance of social realism genre. Friendship with Lenin, influence on the Bolshevik doctrine formation and the adherence to it contributed to the recognition of Gorky in the "new" country. After the revolution, the ideal by Maxim Gorky was partially implemented and embodied in reality, which provoked the writer's mental crisis during the early 20 -ies of the XX-th century. "During that period Gorky was doing a thorough job of freeing his memory from the huge burden of reality. The Russian man, with whom he lived the long years of wandering along the roads of his homeland, passed again in Gorky's seclusion <...> during the prolific time of parting with his past life" (Fedin 1977, p. 118119).

At the same time, it cannot be argued that Gorky was disappointed with what was happening in Soviet Russia. His disappointment is largely psychologically motivated and associated with a sense of historical period completion. The mental crisis is associated not so much with political extremism as with the premonition of the soonest elimination of the political subject from the reality of being. Along with Lunacharsky and other representatives of the Bolsheviks, Maxim Gorky was the builder of a new religious teaching, which, perhaps, provoked a falling out with Lenin. The materialism of the "new" Gorky had a mystical tinge, the sectarianism of the search for the miracle of revelation and grace.

However, the boundaries of the writer's creativity are not limited to ideologized literature. During the post-revolutionary period, there is a decline in the writer's creative activity. This is partly due to the fact that the phenomenon that seemed like a social utopia has become a reality, and partly to the fact that this period is a turning point in the writer's development and artistic thought. During this period, the writer rethinks his previous social experience, builds up the main trends and prospects for the development of creative thought. By this time, the cycle "Tales of 1922-1924" was written in which the reader of "new" Gorky's prose and new heroes became the embodiment of Gorky's ideological crisis. 
K.A. Fedin, having read the cycle of Gorky's stories, excitedly wrote to him: "I am not only your 'old' student, but also an old reader: I have been reading you for about 20 years, since nine hundred and five, when, in fact, I was just beginning to think about something. So, as a reader $<\ldots>$ I want to tell you that I have never experienced such amazement by your books, as now this book ("Tales of 1922-1924") is new to me, and I felt you deeper after it" (Literary heritage 1963, p. 498).

The writer has repeatedly emphasized the importance of stories on the way to large epic form mastering. In particular, he said that the cycle "Tales of 1922-1924" is a test of the pen for the epic novel "Klim Samgin".

Gorky's "new" prose is of great research interest, since it reflects the past, present and future of Russian culture in a concentrated form. "It artistically reveals the most incredible manifestations of old ethical norm collapse, observed later on a worldwide scale. You can find here your favorite ideas, situations, artistic techniques that remain characteristic of the subsequent, so-called "new art" (Ovcharenko 1958: p. 70).

However, the "new" prose by Gorky goes beyond the boundaries of the social and cultural processes taking place in Soviet society, reflecting the world culture as a whole. The First World War, the revolution, as well as the world changes that took place during the first third of the 20th century, contributed to the formation of a new type of hero who survived the shock and was forced to adapt to a new life.

The "new" prose rethinks the experience of a turning point. The new hero by Gorky is a man experiencing an internal crisis associated with the need to adapt to new living conditions. New sociocultural living conditions lead to the need of value rethinking.

\section{Social realism of Gorky's “Tales of 1922 - 1924"}

Maxim Gorky, as the creator of "new prose", departs from the ideological content of prose in the "Tales of 1922 - 1924". His works described how complex life is, how confused and twisted the human psyche is at times, "how ardently a writer must love a person in order to find dear people among the motley, confused inhabitants. These books broke false statements about the need to standardize the range of themes of new art" (Muratova, 1958: p. 246)

The center of his author's attention is the person and his relationship with the social environment. The value criteria in assessing a person become ambiguous, and the person himself is even more contradictory.

If we characterize the genre and stylistic features of the cycle of stories, then it becomes obvious that the story is similar in terms of problems and the amount of information to novels and stories.

The writer created unusual characters in his "Tales of 1922 - 1924". He sought to show that a person is "more complicated than he seems to us" ("The vocation of a writer").

The heroes of Gorky's stories convey the feelings of a significant part of humanity at that time.

"Tales from 1922 - 1924" reveal the writer's inner world. V.G. Veshnev, K.G. Locks, V.B. Shklovsky wrote about the evolution of Gorky's work in the stories. However, the extraordinary worldview depth of the stories was not noted.

The object of Gorky's creativity was the life of people who belong to the social bottom. These are beggars, vagabonds, outcasts, mentally and physically unhealthy people. They are all united by the idea of a just time. This attitude was largely utopian. In the writer's stories, one can trace the creator's awareness that the imaginary world was embodied in specific social conditions. The revolutionary carnival takes many heroes to the streets, where they burn, kill, and the writer saw his own fault in this. The elements of symbolism, impressionism, and existentialism penetrate into the writer's artistic styles.

In the 20-ies of the XX-th century, the genre of the tale prevails in the stories by Gorky, but "unlike the writers of the "fairy tales" who are keen primarily on the play of language and striving mainly to search for individual successful turns of speech or words, Gorky turned speech into only one of the means depicting his characters" (Muratova 1958, p. 242). The stories implement the principles of a novelistic novel, where "the life of the main characters is given 
through the prism of their consciousness and where this prism itself is the subject of depiction and exposure, in connection with which they received a new deepening of psychological analysis" (Bialik 1956, p. 18-19). A.I. Ovcharenko noted that the work "Tales of 1922-1924" captures fashionable "philosophical systems" of our time in a unique form, starting with pragmatism and positivism, Nietzscheanism and Spenglerianism, ending with existentialism and neo-Thomism" (Ovcharenko 1958, p. 70).

Thus, in his stories, Gorky reflects the social realities of his time. The hero becomes more and more complex and contradictory. This is due to the writer's desire to portray a person as he is in the fullness of his feelings and actions.

\section{Hermit Hero in the Social Discourse by Maxim Gorky}

Maxim Gorky's story “The Hermit” was written in 1922. This story has an unusual fate. On the one hand, it was greeted with enthusiasm by A.N. Tolstoy, M.M. Prishvin, translated into many languages, and on the other hand, the story was not appreciated by critics, it was bypassed with due attention. In recent years, the assessment of the story has undergone significant changes. It is often called a "program" work (Gorky's readings 1996, p. 136).

The story is based on the archetype about the great sinner's myth. The idea of the moral rebirth of a fallen man is the core one. This archaic-mythological plot is not new for Russian literature. It corresponds to the theological triad "Sin - repentance - salvation". The triad allows you to penetrate into the recesses of the national spirit. "The mystery of the human, Russian soul torments me. During the four years of the revolution, it has developed so terribly and widely, and flared up so brightly. Will it be burned and remain ashes only or something else?" (Gorky 1973, p. 615). The first attempts to comprehend the ongoing changes in the psychology of the masses are associated with the journalistic articles "On the Russian peasantry" and "Russian cruelty". A lot of them were impulsive. The idea was expressed about the merciless cruelty inherent in Russians. We see the development of these thoughts in the story "The Hermit" by Maxim Gorky.

The semantic field of the story is formed by a number of semantic concepts.

The component "social behavior" is of value in the structure of the concept "hermit". The hero of Gorky's story, Savel the Sawyer, commits extramoral acts. His story of incest with his own daughter looks monstrous. They arrested me, took me to the province, to the prison. I'm imprisoned. The bald one says to me: confess, and you will have an easy execution for that! I kindly offer him: "Let me go, your highness, to Kiev, to the holy relics, to forgive my sins". "You confessed, he said!" So he caught me, a bald cat!

Savel the Sawyer's daughter Tasha is the personification of eternal youth. Tasha is the "star", the "God's beauty". "Of course, I played with her; winter time, the nights are long, it was boring! It is especially boring for someone who is used to spinning on the ground, walking back and forth, and I was like that. I told her fairy tales - I know hundreds of fairy tales. Well, a fairy tale is a false thing. And - the blood is hot. And Tasha ...

He closed his eyes and, shaking his head, sighed:

"She was an impossible beauty! And I, adore women, and become completely insane!"

The sinful relationship with his daughter caused condemnation from those around him, which radically changed the fate of the hero. Savel turned into a homeless wanderer, his daughter Tasha married without love. Tasha's untimely death is perceived by the hero as the consequence of the cunning of people. Speaking about the Fall, Savel speaks with bitterness and resentment of people who persecuted lovers. However, there is no remorse in Savel's story.

The "hero image" component is built in two plans. The foreground is the image of oneself and the image of a literary hero. The appearance of Savel the Sawyer is not pretty: an old man of medium height, somewhat crumpled and bitten. "His face, red, like a brick, is ugly, his left cheek is cut from ear to chin with a deep scar, he twisted his mouth, giving a morbidly mocking expression, his dark eyes were mutilated by trachoma...". The hermit is dexterous, agile "like a ferret". At the same time, there is something in it that attracts to itself. The image of Savel the Sawyer is the image of a hermit. The motive of hermitism is expressed in the very title of the story. Hermitage is a life of solitude. The alienation of Savel the Sawyer is associated with an 
inner need for solitude. "The monks, however, do not like me, everyone invites me to get my hair cut, to become an elder - it is profitable for them, a bait for people, but I don't want it, I'm alive, it doesn't suit me. Am I look like a saint? I am just a friend, a quiet person ..." ".

The component "love" is semantically close to the concept component "hero image". Love took a special place in Savel the Sawyer's life when he lived in the world. "I was cheerful, harmless, like a blessed one, women, girls loved me, well, like sugar, - the right word. What was being done! It is good to remember ...". He attracted the love of women. Savel idolized his beloved women. "I was married, everything was as it should be, my wife, Natalia, is a beautiful soft woman". He treated infidelity in a special way "she had some affairs". "Well, I beat her a little for decency, then I made a present, caressed her: "Fool, I say, you making people laugh at me, how so?"

Savel perceives attraction to a woman as a "big deal": "- Look, friendship: I'm sixty-seven years old, and now I can get every woman to the very end - that's how it is. Five years later, some mares used to pray to me: "Savyolushko, dear, let go, there is no more strength! " You regret her, let her go, but she will be here again in a week. "Why did you come, I ask? That's it!" A woman is friendship, a big deal, the whole earth is raving about it - an animal, a bird, a small insect - all are alive by this! Besides, what else to live with?"

"Service to people" concept component. The main thing in the character of Savel the Sawyer is compassion for destinies, readiness for selfless service.

Advice, the answers to tormenting questions, a kind word make people draw to the hermit. Coming to the hermit Savel, every suffering person finds consolation. Accordingly, hermitry is a religious rite of its own kind, associated with the restriction of one's communication. At the same time, Savel is open to people, ready to come to help at any time. The hermit is full of charm, wisdom, love of life, thereby attracting those who suffer.

A significant role in the image of the "hermit" is played by "nature": the forest ravine, the yellow Oka, the blue river of heaven, bushes, heavy boulders represent the background on the basis of which the main events develop. Savel's departure to nature is conscious. He leaves the new world in the bosom of nature. Here he finds himself. Young trees are a symbol of life, young energy: "Three young trees grow in front of the cave door - linden, birch and maple". Young trees are the signs of the hero's spiritual rebirth.

An integral component of the hermit image is the "hermit's dwelling". Savel's cave is wellbuilt, "and there is a lectern in the corner covered, like brocade, with dense matting, there is an icon lamp in an iron holder on the lectern, its bluish light vibrates. It is barely visible in the gloom". The hermit's dwelling is a holy place. It is no coincidence that there is a lectern in Savel's dwelling, which stands in the middle of every Orthodox church in front of the iconostasis.

The ideas about Savel's "new faith" are formed in the story. The events lead to the fact that people are weak and embittered. They need intimidation. God lives in the soul of every person, you just need to remember about it. The story depicts the stages of a person's spiritual development. Overcoming resentment Savel accepts the duties of a comforter. He achieves mastery in this. The decoration of the cave is "three black icons", "the bundles of new bast shoes", "bast", and "delicious smell of dry herbs". Incense fills the entire cave.

\section{Conclusiones}

Thus, Maxim Gorky's "new prose" occupies a special place in social realism during the first quarter of the 20-th century.

A significant figure in the system of personalities created by the writer is the hermit hero. The hermit hero's image is represented by the component-concepts "social status", "nature", "hero image", "love" and "service to people", the intersection of which creates a unique, in many ways inimitable image of the main character.

The hero of the "new" prose is the hero of the new era, who is full of both attractive and repulsive power. Having become an outcast, Savel the Sawyer is not angry with people. Having discovered a "new" faith, Savel the Sawyer chooses hermitage and helping people as a way of life. 


\section{Referencias}

Bialik, B.A. (1956) Creativity by M. Gorky in the Soviet era. Russia, Moscow, 18-19

Fedin, K.A. (1961) Writer. Art. Time. Russia, Moscow, 98

Fedin, K.A. (1977) Gorky among us. Ch. 2. Russia, Moscow, 118-119

Gorky readings 1995: Materials of the international conf. M. Gorky Today: Problems of Aesthetics, Philosophy, Culture [March 28-29] (1996). Russia, Novgorod, 333

Gorky, A.M. (1973) Full collection of writings. Vol. 17. Russia, Moscow, 739

Klimova, M.N. (2000) Reflection of the myth about the great sinner in the story "The Hermit" by A.M. Gorky. Bulletin of TSPU. Issue 6. Series: Humanities (philology), 39-43

Literary heritage. V. 70. (1963) Gorky and Soviet Writers. Unpublished correspondence. Russia, Moscow, 498

Locks, C.G. (1926) Old and new Gorky. Print and Revolution. Number 3, 22

Muratova, K.D. (1958) M. Gorky in the struggle for the development of Soviet literature. Russia, Moscow, 242

Shklovsky, V.B. (1990) Hamburg reckoning. Articles-essays-memories (1914-1933). Russia, Moscow, 211

\section{Financiamiento:}

* This paper has been support by the RUDN University Strategic Academic Leadership Program. 